

KATA KUNCI perilaku kerja inovatif, kepribadian proaktif, BUMN X

KEYWORDS innovative work behavior, proactive personality, BUMN X

ABSTRAK

ABSTRACT perilaku kerja inovatif.

\section{Hubungan Antara Kepribadian Proaktif dan Perilaku Kerja Inovatif di BUMN X}

\section{The Relationship Between Proactive Personality and Innovative Work Behavior in BUMN X}

\author{
Retno Windiarsih, Arum Etikariena \\ Fakultas Psikologi, Universitas Indonesia, Depok 16424, Indonesia \\ retnowindiarsihh@gmail.com
}

Penelitian ini bertujuan untuk mengukur hubungan antara kepribadian proaktif dan perilaku kerja inovatif. Penelitian dilakukan terhadap 135 karyawan BUMN X yang terdiri dari empat divisi kerja yang sedang mengembangkan inovasi pada aktivitas pekerjaannya. Pengukuran perilaku kerja inovatif mengacu pada alat ukur Skala Perilaku Kerja Inovatif dan terbukti reliabel $(\alpha=0,97)$, sedangkan pengukuran kepribadian proaktif menggunakan alat ukur Skala Kepribadian Proaktif yang telah diadaptasi ke dalam bahasa Indonesia dan terbukti reliabel $(\alpha=0,73)$. Hasil analisis Pearson's Product Moment Correlation menunjukkan adanya hubungan antara kepribadian proaktif dan perilaku kerja inovatif $(r=0,49, p<0,05)$. Dengan demikian, semakin tinggi kepribadian proaktif yang dimiliki karyawan, maka semakin tinggi intensitasnya dalam menampilkan perilaku kerja inovatif. Penelitian ini juga menemukan adanya hubungan yang signifikan antara faktor demografi berupa jenis kelamin dan masa kerja terhadap

This study investigates the correlation between proactive personality and innovative work behavior. This study was conducted among 135 employees working in 4 departments in BUMN X that has been developing an innovation in their work activity. Measurement of IWB refers to Innovative Work Behavior Scale, with $\alpha=0,97$, and measurement of proactive personality used Proactive Personality Scale with $\alpha=0,73$. The results using Pearson's Product Moment Correlation showed there is a significant relationship between proactive personality and innovative work behavior $(r=0,49, p<0,05)$. Thus, the higher the proactive personality, the higher intensity in displaying innovative work behavior. This study also found there are correlations between demographic factors such as gender and tenure organization with innovative work behavior. 


\section{PENDAHULUAN}

Meningkatnya persaingan pasar yang didukung oleh kemajuan teknologi memberikan dampak yang besar bagi setiap perusahaan barang maupun jasa. Tidak hanya mengubah pola interaksi antara penjual dan pembeli, kemajuan teknologi juga mengubah lingkungan pasar menjadi lebih dinamis. Tidak dapat dipungkiri, baik perusahaan dari dalam negeri maupun luar negeri berkompetisi secara global untuk melakukan penyesuaian dengan keadaan saat ini. Berbagai upaya untuk memenuhi kebutuhan konsumen telah dilakukan perusahaan guna menarik minat konsumen agar tetap menggunakan barang atau jasa yang ditawarkan. Hal ini tentu menjadi tantangan yang harus dipenuhi perusahaan untuk tetap bertahan. Adapun salah satu upaya yang dapat dilakukan perusahaan yaitu dengan berinovasi. Tohidi dan Jabbari (2015) menyatakan bahwa selain untuk mempertahankan, inovasi juga berperan penting dalam pertumbuhan suatu perusahaan.

Menurut Van de Ven (1986), inovasi adalah pengembangan dan penerapan ide baru oleh individu yang terlibat dalam interaksi pada suatu susunan organisasi. Ide baru yang dimaksud dapat berupa sebuah penggabungan ide-ide sebelumnya, sebuah rencana untuk memenuhi tantangan saat ini, atau sebuah pendekatan khusus yang dipersepsikan baru oleh individu yang terlibat di dalamnya. Menurut West dan Farr (1990), inovasi adalah pengenalan dan penerapan ide, proses, produk, atau prosedur baru ke dalam kelompok, organisasi atau masyarakat luas yang dimaksudkan untuk memberi keuntungan kepada kelompok, organisasi atau masyarakat luas tersebut. Inovasi merupakan proses yang terdiri dari lebih dari satu tahapan, dengan masing-masing tahap memerlukan aktivitas yang berbeda (Scott \& Bruce, 1994).

Proses inovasi yang terjadi pada suatu organisasi atau perusahaan melibatkan seluruh individu yang terdapat dalam organisasi tersebut. Dalam hal ini individu berperan untuk mengembangkan, membawa, merespon dan memodifikasi ide tersebut (Van de Ven, 1986). Jones (2012) menyatakan bahwa proses inovasi tidak terlepas dari peran sumber daya yang dimiliki individu itu sendiri, semakin banyak pengetahuan yaitu terdiri dari keterampilan, kompetensi, dan pengalaman yang individu peroleh maka aktivitas kerjanya akan menjadi lebih efisien. Pada akhirnya, individu tersebut akan lebih dapat memecahkan masalah yang kompleks, salah satunya untuk memenuhi kebutuhan pasar. Scott dan Bruce (1994) menyebut istilah inovasi pada tingkat individu sebagai individual innovative behavior, yang selanjutnya diterjemahkan sebagai perilaku kerja inovatif.

Perilaku kerja inovatif merupakan upaya yang sengaja dilakukan individu untuk membuat, mengenalkan, dan menerapkan ide baru dalam peran pekerjaannya, kelompok atau organisasi, yang bertujuan memberikan keuntungan bagi individu, kelompok, maupun organisasi (Scott \& Bruce, 1994; Janssen, 2000). Janssen (2000) menambahkan, adapun keuntungan yang diperoleh dapat berupa keberfungsian organisasi yang lebih baik maupun keuntungan sosial-psikologis bagi karyawan sebagai individu atau karyawan sebagai kelompok kerja seperti ketepatan antara persepsi tuntutan kerja dengan sumber daya yang karyawan miliki, meningkatkan kepuasan kerja dan menjadikan komunikasi interpersonal menjadi lebih baik.

Penelitian-penelitian sebelumnya menemukan beberapa faktor terkait munculnya perilaku kerja inovatif. Patterson, Kerrin, dan Gatto-Roisad (2009) membagi faktor terkait perilaku kerja inovatif menjadi dua yaitu faktor personal yang berasal dari dalam diri individu, dan faktor yang berasal dari lingkungan kerja. Adapun aspek yang tercakup dalam faktor internal yaitu kemampuan kognitif, kepribadian, motivasi, pengetahuan, perilaku, emosi dan mood, faktor perkembangan sedangkan aspek yang 
tercakup dalam dalam faktor lingkungan kerja yaitu organizational ambidexterity, merupakan eksplorasi dan eksploitasi yang dilakukan perusahaan, sumber daya yang berasal dari lingkup sosial (karakteristik rekan kerja, karakteristik pemimpin, feedback, social network), desian pekerjaan (karakteristik pekerjaan, tuntutan pekerjaan, lingkungan fisik), dan sumber daya yang berasal dari lingkup organisasi (struktur dan ukuran organisasi, iklim dan budaya organisasi, alokasi sumber daya, insentif dan reward, dan kontrak psikologis).

Inovasi adalah bentuk spesifik dari perubahan di organisasi, karena adanya penerapan ide yang dilakukan untuk meningkatkan suatu produk, proses, atau pun suatu pelayanan (Robbins \& Judge, 2013). Perubahan yang terjadi pada suatu organisasi dilakukan dengan mengubah struktural organisasi, budaya organisasi, dan sumber daya manusia yang tersedia. Strukur organisasi misalnya terkait dengan masa kepemimpinan yang berlaku, karena hal ini dapat memberikan legitimasi dan pengetahuan mengenai cara penyelesaian pekerjaan sehingga memperoleh hasil yang sesuai dengan harapan. Terkait budaya, Robbins dan Judge (2013) menyebutkan bahwa secara umum, budaya yang terdapat pada organisasi cenderung memiliki karakteristik yang sama seperti memberikan reward bagi karyawan yang sukses menampilkan perilaku inovatif. Adapun terkait sumber daya manusia, perusahaan dapat mendorong karyawan untuk melakukan inovasi dengan memberikan pelatihan-pelatihan. Dengan kata lain, perubahan yang terjadi di organisasi dimulai dari perubahan struktural, budaya, kemudian sumber daya manusia, atau dikenal dengan istilah top down. Pelaksanaan perubahan di organisasi mengharuskan seluruh individu, baik yang aktif maupun pasif, untuk beradaptasi dan mengikuti perubahan tersebut.

Janssen (2003) mengatakan bahwa ketika individu menyampaikan sebuah ide untuk membawa perubahan pada organisasi, individu akan menyampaikan ide tersebut kepada rekan kerjanya. Hal yang menjadi permasalahan terjadi ketika rekan kerjanya lebih memilih untuk menghindar dari perubahan yang membuat keadaan sekitar menjadi tidak jelas dan tidak aman bagi dirinya, yang pada akhirnya menghambat terjadinya perubahan pada organisasi. Sementara definisi perilaku inovatif merupakan "upaya yang disengaja...". Dengan kata lain, untuk dapat melakukan perilaku inovatif, dibutuhkan kesediaan individu untuk secara aktif terlibat dalam pelaksanaannya.

Lewin (dalam Bateman \& Crant, 1993) menyatakan bahwa perilaku yang dilakukan individu merupakan hasil interaksi antara disposisi personal dan lingkungan sekitarnya. Hal yang sama juga berlaku dalam memahami perilaku kerja inovatif, bahwa diperlukan kombinasi antara faktor individual dan faktor kontekstual dalam memahami perilaku kerja inovatif. Dari beberapa faktor individual yang berhubungan dengan perilaku kerja inovatif seperti yang telah disebutkan sebelumnya, peneliti tertarik untuk memahami secara mendalam terkait dengan faktor internal individu yaitu kepribadian. Hal ini sesuai dengan pernyataan Robbins dan Judge (2013) yang menyebutkan bahwa faktor yang secara signifikan dapat memengaruhi inividu dalam menampilkan suatu perilaku adalah kepribadian. Adapun kepribadian yang menemukan adanya keaktifan sebagai salah satu faktor yang dimiliki adalah kepribadian proaktif.

Kepribadian proaktif didefinisikan sebagai kecenderungan individu dalam menampilkan perilaku proaktif (Bateman \& Crant, 1993). Perilaku proaktif merupakan tindakan mengambil inisiatif untuk memperbaiki lingkungan sekitar atau membuat lingkungan baru yang lebih baik dengan menantang keadaan tetap (status quo) suatu organisasi, bukan secara pasif menerima keadaan tersebut (Crant, 2000). Dengan kata lain, perilaku proaktif merupakan perilaku yang secara langsung dapat mengubah lingkungan sekitar. 
Sebagai suatu disposisi personal, kepribadian proaktif merupakan konstruk yang mengidentifikasi perbedaan diantara individu sejauh mana mereka mengambil tindakan untuk memengaruhi lingkungan mereka (Crant, 2000). Individu yang proaktif mengubah lingkungannya melalui proses untuk terlibat aktif dalam menunjukkan inisiatif, mengidentifikasi kesempatan dan bertindak untuk memanfaatkan kesempatan tersebut dan relatif tidak terpaksa pada situasi. Bahkan pada situasi yang memaksa sekalipun, individu dengan kepribadian proaktif akan tetap gigih untuk mengubah lingkungan sekitarnya ( $\mathrm{Ng} \&$ Feldman, 2013). Sebaliknya, individu yang kurang proaktif cenderung gagal dalam mengidentifikasi kesempatan bahkan membiarkan kesempatan terjadi begitu saja, dan lebih suka beradaptasi dengan lingkungannya daripada mengubahnya menjadi lebih baik.

Kepribadian proaktif merupakan faktor utama yang memprediksi perilaku kerja inovatif pada karyawan (Pons, Ramon, \& Ramon, 2016). Penelitian tersebut dilakukan pada 458 karyawan yang berasal dari 16 organisasi swasta dari berbagai sektor seperti pendidikan kesehatan, distribusi makanan, konsultasi, transportasi, energi dan industri produksi di Spanyol. Hasil dari penelitian tersebut menunjukkan adanya hubungan positif yang signifikan antara kepribadian proaktif dan perilaku kerja inovatif. Studi lain yang mendukung adanya hubungan antara kepribadian proaktif dengan perilaku kerja inovatif dilakukan oleh Li, dkk (2016). Penelitian tersebut menguji pengaruh kepribadian proaktif terhadap perilaku kerja inovatif yang dimediasi oleh keadaan afektif dan creative self-efficacy pada 352 guru di China. Hasil menunjukkan bahwa kepribadian proaktif berasosiasi positif secara signifikan terhadap perilaku kerja inovatif pada guru. Li, dkk., (2016) menyatakan bahwa kepribadian proaktif menjadi satu kepribadian penting yang memudahkan guru dalam melakukan perilaku inovatif pada pekerjaannya. Hasil tersebut mengindikasikan bahwa kepribadian proaktif merupakan trait kepribadian penting yang memudahkan guru dalam menampilkan perilaku kerja inovatif. Hal ini terjadi karena individu yang proaktif sangat efektif dalam mempromosikan ide mereka sehingga mereka mendapatkan dukungan dari lingkungan sekitarnya untuk menerapkan ide tersebut (Schwaab, Postmes, Van Beest, \& Spears, dalam Giebels, dkk., 2016).

Penelitian lain yang menguji hubungan antara kepribadian proaktif dan perilaku kerja inovatif dilakukan oleh Kim, dkk (2009) yang menghasilkan adanya hubungan positif antara kedua variabel tersebut. Fuller dan Marler (2009) menjelaskan bahwa adanya hubungan positif antara kepriibadian proaktif dan perilaku kerja inovatif terjadi karena individu yang memiliki kepribadian proaktif yang tinggi cenderung memiliki motivasi yang tinggi dalam mengambil inisiatif dan berespon pada situasi yang terjadi di sekitarnya. Individu yang proaktif juga sering mendatangkan ide baru dan akan lebih termotivasi jika ide yang mereka berikan dapat diterapkan pada lingkungan sekitarnya. Schwaab, Postmes, Van Beest, \& Spears (dalam Giebels, dkk., 2016) menegaskan bahwa individu yang proaktif sangat efektif dalam mengenalkan ide mereka sehingga mereka mendapatkan dukungan dari lingkungan sekitarnya untuk menerapkan ide tersebut. Pada akhirnya individu yang proaktif memandang dirinya lebih berhasil dalam merealisasikan idenya (Giebels, dkk., 2016). Oleh karena itu dapat dikatakan bahwa kepribadian proaktif merupakan prediktor penting yang dapat memunculkan perilaku kerja inovatif.

Berdasarkan hasil penelitian yang telah dijabarkan di atas, beberapa penelitian menguji hubungan antara kepribadian proaktif dan perilaku kerja inovatif pada berbagai organisasi swasta dan organisasi yang berfokus pada bidang pendidikan. Penelitian ini akan menguji hubungan antara kedua variabel tersebut pada organisasi BUMN. BUMN merupakan 
organisasi yang modalnya berasal dari pihak swasta dan pemerintah. Meskipun literatur yang membahas kedua variabel pada setting pemerintahan dan swasta terbatas, namun Siswanti (2011) menemukan hasil tidak adanya hubungan antara kepribadian proaktif dan kesuksesan karir pada instansi pemerintahan di salah satu provinsi yang ada di Indonesia. Penelitian tersebut secara tidak langsung berkorelasi dengan perilaku kerja inovatif. Hal ini dibuktikan dengan penelitian jangka panjang terdahulu yang dilakukan Seibert, Kraimer, dan Crant (2001) yang menemukan bahwa perilaku kerja inovatif yang dilakukan karyawan, secara signifikan akan berdampak pada kesukesan karirnya di masa depan.

Partisipan dalam penelitian ini adalah BUMN X, merupakan perusahaan BUMN yang bergerak di bidang pengembangan industri maritim nasional. Sebagai pemegang kunci untuk meningkatkan industri maritim nasional, perusahaan $\mathrm{X}$ berperan penting dalam pemenuhan kebutuhan pasar maritim secara global. Peran penting BUMN $\mathrm{X}$ dalam berinovasi juga didukung oleh salah satu program kerja yang diusung oleh Presiden Republik Indonesia, Joko Widodo, yaitu "menghadirkan kembali negara untuk melindungi segenap bangsa dan memberikan rasa aman pada seluruh warga negara, melalui politik luar negeri bebas aktif, keamanan nasional yang terpercaya dan pembangunan pertahanan negara Tri Matra terpadu yang dilandasi kepentingan nasional dan memperkuat jati diri sebagai negara maritim" (www.kpu.go.id). Dalam hal ini perusahaan $\mathrm{X}$ perlu melakukan inovasi untuk memenuhi semua tuntutan tersebut.

Dalam hal ini, BUMN X merupakan salah satu agen perubahan yang turut andil dalam mengembangkan dan memperkuat jati diri bangsa sebagai negara maritim. Sampai tahun 2014 lalu, upaya inovasi yang dilakukan BUMN $\mathrm{X}$ terlihat cukup signifikan. BUMN $\mathrm{X}$ telah memberikan sumbangsih sebuah karya nyata atas teknologi pembangunan kapal perang. Berbagai jenis kapal perang seperti Fast Parpol Boat $57 \mathrm{KM}$, Landing Platform Deck 125 M, Submarine DSME 209, membuktikan sebuah pengembangan inovasi teknologi BUMN $\mathrm{X}$ (JakartaGreater.com). Hingga saat ini, BUMN X mulai kembali mengembangkan inovasi pada produknya. BUMN $\mathrm{X}$ menargetkan akan menyelesaikan kapal inovasi Landing Platform Deck selama 23 bulan terhitung mulai Mei 2017yang akan digunakan untuk memperkuat armada laut yang secara tidak langsung juga berfungsi untuk memperkuat jati diri bangsa sebagai negara maritim. Adapun keunggulan yang membedakan kapal ini dengan kapal Landing Platform Deck sebelumnya adalah kapasitas pengangkutan yang lebih besar (berkasnews.com). Oleh karena itu, BUMN $\mathrm{X}$ memiliki peranan penting dalam merealisasikan cita-cita bangsa. Untuk dapat merealisasikan cita-cita tersebut diperlukan inovasi dari seluruh sumber daya manusia yang tersedia. Oleh karena itu, hipotesis yang terdapat dalam penelitian ini adalah "Terdapat hubungan yang signifikan antara tipe kepribadian proaktif dengan perilaku kerja inovatif pada karyawan di BUMN X".

\section{METODE PENELITIAN}

Berdasarkan Kumar (2005) penelitian ini merupakan penelitian korelasi yang bertujuan untuk mengetahui hubungan antara dua variabel yaitu kepribadian proaktif dan perilaku kerja inovatif. Adapun hasil yang diperoleh dari penelitian ini dapat diterapkan pada secara praktis oleh perusahaan. Sementara berdasarkan perspektif teknik pengambilan data, penelitian ini tergolong dalam penelitian terstruktur, atau disebut penelitian kuantitiatif, karena hasil penelitian ini berbentuk kuantitatif yang kemudian dianalisa untuk menjelaskan hubungan antara kedua variabel.

Berdasarkan tiga perspektif, desain pada penelitian ini digolongkan menjadi crosssectional study, karena hanya melakukan 
satu kali pengambilan data. Penelitan ini juga tergolong retrospective study, karena dilakukan untuk mengetahui fenomena, situasi, masalah yang telah terjadi sebelumnya. Dalam penelitian ini yaitu mengukur hubungan kepribadian proaktif dan perilaku kerja inovatif yang telah dilakukan karyawan perusahaan X. Selain itu, penelitian ini juga tergolong sebagai non-experimental study karena dilakukan untuk mengetahui hubungan sebab akibat antara dua variabel serta tidak memberikan stimulus atau pun manipulasi pada subjek penelitian.

Populasi dalam penelitian ini adalah karyawan yang bekerja di BUMN X yang telah bekerja selama lebih dari satu tahun, sedangkan sampel penelitian ini merupakan karyawan yang berasal dari divisi kapal perang, divisi kapal niaga, divisi rekayasa, dan divisi desain. Pengambilan sampel dilakukan dengan teknik nonprobability sampling yang dilakukan dengan cara menyebar kuesioner secara langsung. Dari keempat divisi tersebut, peneliti menyebarkan kuesioner sebanyak 160 buah kuesioner, sedangkan kuesioner yang dapat digunakan dan diolah berjumlah 135 buah. Dalam proses pengumpulan data, peneliti mendatangi perusahaan kemudian menyebar kuesioner secara langsung. Peneliti memberikan waktu selama satu sampai dengan dua minggu untuk mengisi kuesioner yang telah diberikan. Kemudian peneliti mengambil kembali kuesioner yang telah diisi tersebut pada hari yang telah dijanjikan pihak perusahaan $\mathrm{X}$.

Pengukuran variabel dalam penelitian ini menggunakan Skala Perilaku Kerja Inovatif yang dikembangkan Janssen (2000) dan telah diadaptasi oleh Etikariena dan Muluk (2014) dengan koefisien alpha sebesar 0,97. Alat ukur ini terdiri dari 9 butir pernyataan dengan 3 butir mewakili setiap tahapan inovatif kerja. Dengan 6 skala Likert yang digunakan, teknik skoring yang berlaku yaitu nilai 1 "Jika belum pernah sama sekali melakukan", sampai 6 "jika selalu melakukan". Adapun skor minimal yang dapat diperoleh individu adalah 9, dan skor maksimalnya adalah 54 . Berikut ini akan dicantumkan tabel kisi-kisi dari alat ukur Skala Perilaku Kerja Inovatif yang digunakan.

Tabel 1. Kisi-Kisi Alat Ukur Skala Perilaku Kerja Inovatif

\begin{tabular}{|c|c|c|}
\hline No & Tahapan & Item \\
\hline 1 & $\begin{array}{l}\text { Menciptakan } \\
\text { Ide (Idea } \\
\text { generalization) }\end{array}$ & $\begin{array}{l}\text { Mencari metode kerja } \\
\text { yang baru di pekerjaan } \\
\text { saya. }\end{array}$ \\
\hline 2 & $\begin{array}{l}\text { Mengenalkan } \\
\text { Ide (Idea } \\
\text { promotion) }\end{array}$ & $\begin{array}{l}\text { Mendapatkan } \\
\text { persetujuan untuk ide- } \\
\text { ide inovatif yang saya } \\
\text { sampaikan }\end{array}$ \\
\hline 3 & $\begin{array}{l}\text { Menerapkan } \\
\text { Ide (Idea } \\
\text { realization) }\end{array}$ & $\begin{array}{lr}\text { Mewujudkan } & \text { ide-ide } \\
\text { inovatif } & \text { menjadi } \\
\text { aplikasi atau } & \text { program } \\
\text { yang } & \text { dapat } \\
\text { dilaksanakan. } & \end{array}$ \\
\hline
\end{tabular}

Sementara pengukuran kepribadian proaktif menggunakan Skala Kepribadian Proaktif yang dikembangkan Bateman dan Crant (1993) dan telah diaptasi Sari (2015) dengan koefisien alpha sebesar 0,73. Alat ukur ini terdiri dari 17 butir pernyataan. Skoring yang digunakan yaitu 6 Likert dengan rentang pilihan jawaban 1 sampai 6 (1="Sangat Tidak Setuju", $6=$ "Sangat Setuju"). Sebaliknya, pada item unfavorable, skoringnya menjadi 1="Sangat Setuju", 6 = "Sangat Tidak Setuju". Dengan demikian, skor total minimal yang dapat diperoleh individu adalah 17 , dan skor total maksimalnya adalah 102. Adapun hasil pengujian validitas alat ukur Proactive Personality Scale adalah berada di rentang nilai 0,03 sampai dengan 0,60. Peneliti melakukan revisi terhadap beberapa item yang dianggap tidak baik karena memiliki nilai corrected item-total correlation $<3$, sehingga dapat menurunkan nilai reliabilitas item. Berikut adalah contoh item yang direvisi. 
Tabel 2. Contoh Revisi Item

\begin{tabular}{|c|c|c|}
\hline No & Item sebelumnya & Item Revisi \\
\hline 1 & $\begin{array}{l}\text { Jika saya melihat } \\
\text { sesuatu yang tidak } \\
\text { saya sukai, maka } \\
\text { saya tidak akan } \\
\text { menanggapinya } \\
\end{array}$ & $\begin{array}{l}\text { Jika saya melihat } \\
\text { sesuatu yang tidak } \\
\text { saya sukai, maka } \\
\text { saya akan } \\
\text { memperbaikinya }\end{array}$ \\
\hline No & Item sebelumnya & Item Revisi \\
\hline 2 & $\begin{array}{l}\text { Saya adalah orang } \\
\text { yang cenderung } \\
\text { menghindari } \\
\text { masalah dan } \\
\text { memilih untuk tidak } \\
\text { menghadapinya } \\
\text { secara langsung }\end{array}$ & $\begin{array}{l}\text { Saya mampu } \\
\text { menghadapi } \\
\text { masalah yang saya } \\
\text { alami }\end{array}$ \\
\hline 3 & $\begin{array}{l}\text { Saya tidak mampu } \\
\text { memperjuangkan } \\
\text { ide saya jika ada } \\
\text { beberapa orang } \\
\text { yang menentangnya }\end{array}$ & $\begin{array}{l}\text { Saya suka } \\
\text { memperjuangkan } \\
\text { ide saya, meskipun } \\
\text { orang lain } \\
\text { menentangnya }\end{array}$ \\
\hline
\end{tabular}

Teknik pengolahan data yang digunakan dalam penelitian ini yaitu analisis deskriptif, Pearson's Product Moment Correlation, Analysis of Variance One-Way ANOVA, dan Independent Sample T-Test. Analisis deskriptif, digunakan untuk mengukur gambaran umum karakteristik partisipan yang mencakup nilai rata-rata, nilai maksimum dan nilai minimum dari variabel kepribadian proaktif dan perilaku kerja inovatif, frekuensi, dan standar deviasi. Pearson's Product Moment Correlation, untuk mengukur kekuatan hubungan antara kepribadian proaktif dan perilaku kerja inovatif. Melalui teknik ini, peneliti juga dapat melihat arah hubungan dari kedua variabel tersebut. Analysis of Variance One-Way ANOVA, untuk mengukur signifikansi dengan membandingkan mean lebih dari dua kelompok pada karaktersitik usia, pendidikan, dan lama bekerja. Independent Sample T-Test, digunakan untuk mengukur signifikansi dengan membandingkan mean dari kedua kelompok yang ada pada karakteristik jenis kelamin.

\section{HASIL DAN DISKUSI}

Dari hasil pengolahan data didapatkan hasil bahwa karakteristik usia, sebanyak 69 partisipan atau sebesar $51,1 \%$ berada pada rentang usia 25-44 tahun ( $M=36,97$, $\mathrm{SD}=13,11)$. Pada karakteristik jenis kelamin sebagian besar partisipan dalam penelitian ini didominasi oleh partisipan berjenis kelamin laki-laki sebanyak 98 partisipan atau sebesar 72,6\%. Adapun pada karakteristik pendidikan, sebanyak 52 partisipan berada pada tingkat pendidikan S1 dengan presentase $38,5 \%$. Sementara pada karakteristik masa kerja, sebanyak 72 partisipan atau sebesar 53,3\% telah bekerja selama lebih dari 10 tahun.

Adapun gambaran variabel perilaku kerja inovatif dan kepribadian proaktif di BUMN $\mathrm{X}$ menunjukkan bahwa nilai rata-rata perilaku kerja inovatif partisipan adalah sebesar 34,13, dengan standar deviasi sebesar 12,15. Adapun skor tertinggi yang diperoleh partisipan adalah sebesar 54, sedangkan skor terendah adalah 9. Dari tabel tersebut juga dapat diketahui bahwa skor rata-rata kepribadian proaktif yang diperoleh partisipan yaitu sebesar 78,82 , dengan nilai standar deviasi sebesar 7,6. Adapun skor terendah yang didapatkan partisipan adalah sebesar 61 dan skor tertinggi sebesar 102 .

Gambaran perilaku kerja inovatif dikelompokkan menjadi dua kategori, yaitu kategori rendah dan tinggi. Kategori tersebut dibuat berdasarkan mean skala yang digunakan dalam penelitian ini. Berdasarkan perhitungan tersebut dapat diketahui bahwa sebanyak 66 karyawan di BUMN $X$ memiliki intensitas dalam menampilkan perilaku kerja inovatif yang rendah $(48,9 \%)$, sedangkan sebanyak 69 karyawan memiliki intensitas dalam menampilakan perilaku kerja inovatif yang tinggi $(51,1 \%)$. Sementara itu, gambaran kepribadian proaktif juga dikelompokkan menjadi dua kategori, yaitu kategori rendah dan tinggi. Kategori tersebut dibuat berdasarkan norma kelompok dengan memperhitungkan nilai rata-rata yang diperoleh dari partisipan penelitian. 
Berdasarkan perhitungan tersebut, diketahui bahwa sebanyak 67 karyawan di BUMN X memiliki kecenderungan yang rendah untuk menampilkan perilaku peroaktif $(49,6 \%)$, sedangkan sebanyak 68 karyawan memiliki kecenderungan yang tinggi untuk menampilkan perilaku peroaktif $(50,4 \%)$.

Hasil korelasi menggunakan teknik analisis statistik Pearson's Product Moment Correlation menunjukkan nilai korelasi $\mathrm{r}=$ 0,49 , signifikan pada $\mathrm{p}<0,05$ (one tailed). Berdasarkan nilai $\mathrm{r}^{2}$ yang diperoleh yaitu 0,24, maka dapat dikatakan bahwa $24 \%$ varians dari perilaku kerja inovatif dapat dijelaskan dengan kepribadian proaktif, sedangkan $86 \%$ varians dijelaskan dengan variabel lain. Hal ini menunjukkan bahwa Ha diterima, sehingga dapat disimpulkan bahwa terdapat hubungan yang signifikan antara kepribadian proaktif dengan perilaku kerja inovatif, semakin tinggi skor kepribadian proaktif individu maka semakin tinggi intensitas individu dalam menampilkan perilaku kerja inovatif. Hasil ini mendukung hasil temuan pada penelitian sebelumnya yang mengatakan adanya hubungan yang signifikan antara kepribadian proaktif dan perilaku kerja inovatif (Li, dkk, 2016; Giebels, dkk, 2016; Pons, Ramos, \& Ramos, 2016). Hasil penelitian ini menunjukkan bahwa perilaku kerja inovatif yang ditampilkan oleh karyawan di BUMN X didasarkan pada inisiatif untuk memanfaatkan kesempatan yang ada, hingga mengubah lingkungan kerjanya menjadi lebih baik dan efisien, yang kemudian akan memberikan keuntungan baik bagi dirinya, maupun bagi organisasi. Sesuai dengan penelitian sebelumnya, dapat dikatakan bahwa kepribadian proaktif membantu karyawan dalam melakukan perilaku inovatif pada pekerjaannya (Li, dkk, 2016).

Aspek demografis yang dipertimbangkan dalam penelitian ini adalah usia, jenis kelamin, tingkat pendidikan, dan masa kerja. Berdasarkan perhitungan statistik yang dilakukan, diperoleh hasil sebagai berikut:

Tabel 4. Gambaran Perilaku Kerja Inovatif Berdasarkan Data Demografi

\begin{tabular}{lcc}
\hline \multicolumn{1}{c}{ Keterangan } & Mean Kepribadian Proaktif & $\boldsymbol{P}$ \\
\hline Usia $\quad$ < 25 tahun & 74,82 & 0,15 \\
$-\quad 25-44$ tahun & 79,19 & $\mathrm{~F}=1,9$ \\
$-\quad 45-64$ tahun & 79,72 & \\
Jenis Kelamin & & \\
$-\quad$ Laki-laki & 78,96 & 0,58 \\
$-\quad$ Perempuan & 79,00 & $\mathrm{t}=-0,02$ \\
$\begin{array}{l}\text { Tingkat Pendidikan } \\
-\quad \text { SMA/SMK/STM/SLTA }\end{array}$ & & \\
$-\quad$ Diploma & 79,77 & 0,46 \\
$-\quad$ S1 & 76,84 & $\mathrm{~F}=0,86$ \\
$-\quad$ S2 & 78,86 & \\
Masa kerja & 83 & \\
$-\quad$ 2 tahun & & \\
\hline
\end{tabular}




\begin{tabular}{lll}
\hline$-\quad 2-10$ tahun & 76,80 & $\mathrm{~F}=2,92$ \\
$-\quad>10$ tahun & 80,29 &
\end{tabular}

Berdasarkan tabel 4, dapat diketahui bahwa partisipan yang berusia 45-64 tahun memiliki skor perilaku kerja inovatif yang lebih tinggi $(M=35,49)$ dibandingkan dengan partisipan yang berusia $<25$ tahun $(\mathrm{M}=29,36)$ dan partisipan yang berusia 25 -44 tahun $(M=34,23)$. Namun, perbedaan rata-rata skor yang diperoleh tidak signifikan, dengan nilai $\mathrm{F}(2,118)=1,08, \mathrm{p}$ $>0,05$. Hasil perhitungan pada aspek tingkat pendidikan juga diperoleh tidak adanya perbedaan yan signifikan antara karyawan dengan tingkat pendidikan SMA sederajat $(\mathrm{M}=36,52)$, Diploma $(\mathrm{M}=$ 31,68), dan $\mathrm{S} 1(\mathrm{M}=32,60)$. dan $\mathrm{S} 2(\mathrm{M}=$ 45) dengan nilai $F(3,117)=1,73, p>0,05$. Hal ini diasumsikan terjadi karena sampel dalam penelitian ini merupakan karyawan yang berasal dari divisi dengan tipe pekerjaan yang lebih menekankan pada aktivitas kerja yang bersifat teknis daripada kognitif.

Partisipan yang berjenis kelamin laki-laki memiliki skor perilaku kerja inovatif yang lebih tinggi $(\mathrm{M}=35,78)$ daripada partisipan berjenis kelamin perempuan $(\mathrm{M}=27,57)$, dan memiliki perbedaan rata-rata skor yang signifikan dengan nilai $\mathrm{t}(119)=2,98, \mathrm{p}<$ 0,05 . Hal ini menunjukkan adanya perbedaan antara karyawan laki-laki dan karyawan perempuan dalam menampilkan perilaku kerja inovatif, yaitu karyawan lakilaki pada BUMN X lebih menampilkan perilaku kerja inovatif dibandingkan dengan karyawan perempuan. Hal ini mungkin terjadi karena perempuan yang menjadi partisipan dalam penelitian ini sebagian besar menjabat sebagai staf, dan administrator. Scott dan Bruce (1994) menyebutkan bahwa tidak semua peran kerja memerlukan individu untuk menjadi inovatif. Sesuai dengan pernyataan berikut, peneliti berasumsi bahwa peran karyawan perempuan sebagai staf dan administrator tidak memerlukan karyawan untuk menampilkan perilaku kerja inovatif.
Namun, bukan berarti peran sebagai staf dan administrator benar-benar tidak perlu menampilkan perilaku kerja inovatif, hanya saja proporsi karyawan pada jabatan tersebut tidak lebih besar daripada peran kerja sebagai manager atau kepala biro. Hal ini juga sesuai dengan pernyataan Pons, Ramos, dan Ramos (2016) bahwa perempuan cenderung termotivasi melakukan perilaku inovatif terkait dengan tipe pekerjaan tertentu. Tipe pekerjaan yang ada pada peran administrator, memiliki rutinitas pekerjaan yang cenderung stabil yang kemudian berdampak pada rendahnya perilaku kerja inovatif yang ditampilkan.

Selanjutnya, perhitungan menunjukkan adanya perbedaan skor rata-rata yang signifikan pada partisipan yang telah bekerja selama lebih dari 10 tahun $(\mathrm{M}=$ 36,54) dibandingkan dengan partisipan yang telah bekerja kurang dari 2 tahun $(\mathrm{M}=$ 28,5) dan partisipan yang telah bekerja selama 2 sampai 10 tahun $(\mathrm{M}=31,12)$, dengan nilai $\mathrm{F}(2,118)=3,47, \mathrm{p}<0,05$. Hal ini sesuai dengan pernyataan Liu, Ge, dan Peng (2016) bahwa masa kerja di organisasi membantu individu untuk mengumpulkan informasi terkait pengetahun deklaratif dan prosedural. Pengetahuan deklaratif merupakan informasi berupa fakta-fakta yang tersimpan dalam memori dan bersifat statis, biasanya berupa pengetahuan yang menggambarkan segala sesuatu, sedangkan pengetahuan prosedural merupakan pengetahuan tentang bagaimana cara untuk melakukan sesuatu (Pezzulo, 2011). Baik pengetahuan deklaratif maupun prosedural, merupakan pengetahuan yang penting untuk menunjang individu dalam menampilkan perilaku kerja inovatif. Sesuai dengan hal tersebut, dapat disimpulkan bahwa karyawan pada BUMN X yang telah bekerja selama lebih dari 10 tahun lebih dapat memanfaatkan pengetahuan yang diperoleh selama bekerja sehingga menjadikan pekerjaannya menjadi lebih 
efektif dan efisien dengan melakukan perilaku kerja inovatif daripada karyawan yang bekerja selama kurang dari 10 tahun.

\section{KESIMPULAN}

Berdasarkan analisis dan hasil penelitian di atas, peneliti menyimpulkan bahwa kepribadian proaktif berhubungan positif secara signifikan terhadap perilaku kerja inovatif pada karyawan di BUMN X, artinya semakin tinggi tingkat kepribadian proaktif yang dimiliki karyawan maka semakin tinggi intensitas karyawan tersebut dalam menampilkan perilaku kerja inovatif dan sebaliknya. Gambaran perilaku kerja inovatif pada karyawan di BUMN X menunjukkan bahwa sebanyak 53 karyawan memiliki skor perilaku kerja inovatif yang rendah dan 82 karyawan memiliki skor perilaku kerja inovatif yang tinggi, sedangkan gambaran kepribadian proaktif pada karyawan di BUMN X menunjukkan bahwa sebanyak 67 karyawan memiliki skor kepribadian proaktif yang rendah, sedangkan selebihnya 68 karyawan memiliki skor kepribadian proaktif yang tinggi.

Berdasarkan hasil perhitungan independent simple t-test dan analysis of variance (ANOVA) tersebut, dapat disimpulkan bahwa faktor demografis berupa jenis kelamin dan masa kerja memiliki perbedaan skor rata-rata yang signifikan pada karyawan di BUMN X, sedangkan pada karakteristik usia dan tingkat pendidikan ditemukan tidak adanya perbedaan skor yang signifikan pada karyawan di BUMN X.

\section{SARAN}

Saran yang dapat diberikan terkait dengan hasil penelitian yaitu perusahaan dapat mendorong karyawannya untuk terlibat aktif dalam menampilkan perilaku proaktif untuk mengubah lingkungan kerjanya menjadi lebih baik, karena semakin tinggi karyawan melakukan perilaku proaktif maka semakin tinggi intensitasnya untuk menampilkan perilaku kerja inovatif dalam aktivitas kerjanya. Salah satu hal dapat dilakukan adalah dengan memberikan reward atau insentif bagi seluruh karyawan yang berhasil menampilkan perlaku proaktif, sehingga nantinya dapat menampilkan perilaku kerja inovatif.

Selain itu sesuai dengan hasil penelitian yang menemukan bahwa karyawan cenderung menampilkan perilaku kerja inovatif terkait dengan tipe pekerjaan tertentu. Tipe pekerjaan tertentu akan memiliki peran serta tugas kerja yang berbeda pada karyawan untuk menampilkan perilaku kerja inovatif. Sejalan dengan hal tersebut, hasil penelitian ini dapat dijadikan sebagai pertimbangan perusahaan untuk melakukan pemetaan ketika menyeleksi karyawan, misalnya dengan menempatkan calon karyawan yang memiliki tingkat keprabadian proaktif yang tinggi pada tipe pekerjaan atau jabatan yang memang memerlukan inovasi yang tinggi dan begitu pula sebaliknya. Dengan demikian, karyawan yang terpilih untuk menempati jabatan atau posisi tertentu benar-benar sesuai dengan harapan perusahaan. 


\section{UCAPAN TERIMA KASIH}

1. Terima kasih kepada pihak Fakultas Psikologi Universitas Indonesia yang telah memberikan hibah Penelitian Payung Skripsi dengan tema Perilaku Kerja Inovatif sehingga penelitian ini dapat terselesaikan dengan baik.

2. Terima kasih juga saya sampaikan kepada Arum Etikariena, S.Psi, M.Psi di Fakultas Psikologi Universitas Indonesia, yang telah membimbing, memberikan saran

\section{DAFTAR PUSTAKA}

Bateman, T. S., \& Crant, J. M. (1993). The proactive component of organizational behavior: A measure and correlates. Journal of organizational behavior, 14(2), 103-118.

Crant, J. M. (2000). Proactive behavior in organizations. Journal of management, 26(3), 435-462.

Etikariena, A., \& Muluk, H. (2014). Correlation between Organizational Memory and Innovative Work Behavior. Makara Hubs-Asia, 8(3), 77-88.

Fuller, B., \& Marler, L. E. (2009). Change driven by nature: A meta-analytic review of the proactive personality literature. Journal of Vocational Behavior, 75, 329345. doi:10.1016/j.jvb.2009.05.008

Giebels, E., de Reuver, R. S., Rispens, S., \& Ufkes, E. G. (2016). The Critical Roles of Task Conflict and Job Autonomy in the Relationship Between Proactive Personalities and Innovative Employee Behavior. The Journal of Applied Behavioral Science, 52(3), 320-341.

Janssen, O. (2000). Job demands, perceptions of effort-reward fairness and innovative work behaviour. Journal of Occupational and organizational psychology, 73(3), 287-302.

Janssen, O. (2003). Innovative behaviour and job involvement at the price of conflict and less satisfactory relations with coworkers. Journal of occupational and organizational psychology, 76(3), 347364. dan arahan dalam setiap proses berjalannya penelitian ini.

3. BUMN X, yang telah membantu peneliti dalam pengambilan data penelitian.

4. Sebagai penutup, ucapan terima kasih saya sampaikan kepada Erita Marisdianti, S.Psi, dan Putri Bayu Gusti Megantari Pratiwi, S.Psi yang telah memberikan dukungan dan saran melalui diskusi selama proses pengerjaan penelitian.

Jones, B. (2012). Innovation and human resources: Migration policies and employment protection policies. NESTA: Compendium of Evidence on the Effectiveness of Innovation Policy Intervention. Manchester, Manchester Institute of Innovation Research, University of Manchester.

Kim, T. Y., Hon, A. H. Y., \& Crant, J. M. (2009). Proactive personality, employee creativity, and newcomer outcomes: A longitudinal study. Journal of Business and Psychology, 24, 93-103. doi:10.1007/s10869-009-9094-4

Kumar,R. (2005). Research methodology: A step-by-step guide for beginners. $2^{\text {nd }} \mathrm{Ed}$. London: Sage Publication Ltd.

Li, M., Liu, Y., Liu, L., \& Wang, Z. (2016). Proactive personality and innovative work behavior: the mediating effects of affective states and creative self-efficacy in teachers. Current Psychology, 1-10.

Li, N., Liang, J. and Crant, J.M. (2010), "The role of proactive personality in job satisfaction and organizational citizenship behavior: a relational perspective", Journal of Applied Psychology, Vol. 95 No. 2, pp. 395-404.

Liu, Z., Ge, L., \& Peng, W. (2016). How organizational tenure affects innovative behavior? The role of culture difference and status determinants. Nankai Business Review International, 7(1), 99-126.

Patterson, F., Kerrin, M., \& Gatto-Roissard, G. (2009). Characteristics and behaviours of innovative people in organisations. Literature Review prepared for the NESTA Policy \& Research Unit, 1-63. 
Pons, F. J., Ramos, J., \& Ramos, A. (2016). Antecedent variables of innovation behaviors in organizations: Differences between men and women. Revue Européenne de Psychologie Appliquée/European Review of Applied Psychology, 66(3), 117-126.

Robbins, S. P., \& Judge, T. A. (2013). Organizational Behavior $\left(13^{\text {th }}\right.$ Ed). Pearson Education, Inc.

Sari, S. M. (2015). Hubungan antara kepribadian proaktif dan kemandirian belajar pada mahasiswa Universitas Indonesia (Skripsi). Depok: Universitas Indonesia

Scott, S. G., \& Bruce, R. A. (1994). Determinants of innovative behavior: A path model of individual innovation in the workplace. Academy of management journal, 37(3), 580-607.

Seibert, S. E., Crant, J. M., \& Kraimer, M. L. (1999). Proactive personality and career success. Journal of applied psychology, 84(3), 416.

Seibert, S. E., Kraimer, M. L., \& Crant, J. M. (2001). What do proactive people do? A longitudinal model linking proactive personality and career success. Personnel psychology, 54(4), 845-874.

Van de Ven, A. H. (1986). Central problems in the management of innovation. Management Science, 32(5), 590-607.

West, M. A., \& Farr, J. L. (1990). Innovation at work. In M. A. West \& J. L. Farr (Eds.), Innovation and creativity at work (pp. 113). Chichester: Wiley. 